\title{
Reconsidering Learning-oriented Assessment in Design Education: Challenges and Opportunities
}

\author{
Derya Yorgancioğlu \\ Dr., Department of Architecture, Özyeğin University, İstanbul, Turkey
}

\begin{abstract}
.
This study re-contextualizes the debates on the challenges and opportunities of assessment in design education into the broader context of the literature on assessment in higher education by highlighting key issues of particular relevance to the design feedback procedures and studio-based learning. The focus in this paper is on three main problematic issues: (1) the role of ingrained conventions of assessment that informs the design studio tutors' teaching practices, (2) the role of language and one-to-one communication in design feedbacks, and (3) the difficulty of evaluating the subjective design process objectively. The study is based on a qualitative research and the data collection process covers a systematic and extensive literature survey with a special focus on formative assessment in higher education, and its implications to assessment in design education. The literature survey is followed by an indepth thematic analysis of publications that is based on identifying the key themes related with the research questions. In this study it is revealed that formative assessment feedback plays a critical role in encouraging the active participation of design students in the learning processes and supporting their development as self-assessors. The study presented a valuable framework for moving the research agenda further into how design studio assessment practices can be improved in order to support studio-based learning in design education and how assessment can be reconsidered in a way to foster learning throughout life.
\end{abstract}

Keywords: design feedback; design studio assessment; formative assessment; higher education; studio-based learning.

\section{Introduction}

Design education depends on: (1) given design problem as the beginning of design project; (2) the tutor and the student as actors interacting with each other; (3) the background, belief systems and values of tutors and students, (4) the procedures of assessment and evaluation; and, finally (5) the studio environment as a physical and social context for design learning (Cross, 2004; McDonnell, 2016). The social environment of the design studio derives from the communication and interaction channels between tutor-students and students-students. This interaction is primarily generated through "design critique" as the principle pedagogical tool of feedback that is practiced in the design studio (Oh et al., 2012). When assessment and evaluation in design education is at issue, of primary importance is a process that occur at the centre of the design studio. Design education dwells on "studio-based pedagogy" that dwells on a "project-centred learning approach" (Orr \& Bloxham, 2012, p. 235). Students get feedback from the tutor throughout the process of design project; one-to-one dialogue between the tutor and the student allows the student to realize the positive/negative aspects of their projects, to re-evaluate the potentials that can be developed further (Swann, 2002). The 
20-22 March, 2020

Berlin, Germany $10^{\text {th }}$ International Conference on Humanities, Psychology \& Social Sciences

feedback process is practiced not only from tutor to students, but among the students as they express their ideas and criticism about their friends' projects in the studio environment (Gray, 2013; Belluigi, 2016). The development of design expertise for students is realized through the active engagement of both the tutor (as a role model, involving the his/her expertise and professional experiences) and the students (involving his/her previous experiences and learning orientations) to the learning process.

The complex nature of assessment in higher education has always been problematic. Both the instructor and the students take part in this complexity. On the one hand, instructors' conceptions about teaching and learning, their previous learning experiences, their ingrained conventions about assessment that shape their teaching practices have impact on what they focus in regard to assessment (Shreeve et al., 2010). As underlined by Samuelowicz and Bain (2002), the orientations toward assessment for instructors who conceptualizes teaching as "exposition, and learning as reproduction" and for whom teaching is "facilitating learning, and learning as constructing a personal understanding based upon established knowledge and procedure" differ from each other: for the first, "assessments should determine how well students can reproduce the knowledge they have been given and how well they can use that knowledge in much-practised task," whilst for the second, "assessments should require purposeful transformation of knowledge to address open ended issues or problems not previously encountered" (Samuelowicz \& Bain, 2002, p. 196). It is also discussed that the instructors' approaches to assessment can be teacher-focused although they hold a studentcentred understanding of learning, or they may follow a student-focused approach to assessment even if their teaching practice can be based on reproduction of expert knowledge (Brown, 2003, cited in Drew \& Shreeve, 2005, pp. 6-7).

When design education is concerned, assessment becomes even more complex (Orr, 2007). In evaluating a design project, "the judgments of quality [of the project] are often based on unquantifiable dimensions" (Smith, 2013, p. 211). The evaluation process covers judgments about the design project's qualifications, and the tutor makes these judgments with regard to his/her own designer expertise and educator experience. In the view of Smith (2013), there should be a balance between "judgement-based" and objective criteria based assessment in design education. Additionally, students' prior knowledge and experiences, their personal abilities, their conceptions of teaching and learning, their learning styles, their concerns for grading are instrumental in how the students conceive assessment. Thus, tutors' and students' conceptions of assessment can be different (Drew \& Shreeve, 2005). The following questions can hardly have a definite answer when design education is concerned: What is being assessed/evaluated? What are the evaluation criteria? What are the tools, means and channels of assessment? What are the expected contributions of assessment to design learning and to the development of design expertise? This paper argues that the problems persistent in assessment and evaluation procedures in design education can be addressed under 3 main topics: (1) lack of pedagogical formation of tutors and the effect of their own educational experiences / traditions on their current assessment practices, (2) the difficulties of evaluating the subjective design process objectively, (3) evaluation difficulties resulting from communication modalities/genres in design education based on one-to-one communication among individuals. 
20-22 March, 2020

Berlin, Germany $10^{\text {th }}$ International Conference on Humanities, Psychology \& Social Sciences

\subsection{Background: The relationship between assessment and learning}

As aforementioned, the critique / feedback focus constitutes the basis of evaluation approaches in design education. An inquiry of assessment in design education should address, the facts that design education depends on the 'process' and the 'educational value of evaluation' gains importance within this process as much as the product. Design evaluation is related to the learning in a creative process experienced by the students. Accordingly, the crit as the general phase encompassing the methods of desk critique, peer review or jury, is based on both formative and summative feedback procedures (Blair, 2006; Blythman, Blair \& Orr, 2008).

In the past two decades, numerous studies in higher education literature inquired the varying views on assessment and the critical role of assessment in the learning process. Biggs (2003) points to need for an "alignment between what we want, how we teach and how we assess" (p. 27). In the view of Ellmers et al., (2008), assessment should be "part of and feed into the learning process, not simply be a quantifiable measure of it" (p. 3). This necessitates initiatives for increasing learning capacity of students and their general development by encouraging their active participation into the learning processes. Drew and Shreeve (2005) underline the contribution of educational researches to the growing body of knowledge on "the ways in which assessment influences what students learn and how they learn" (p. 1). What is more, it is discussed that assessment should be designed in accordance with the objectives of a course, discipline, profession and higher education (Raison \& Pelliccione, 2006). For Samuelowicz and Bain (2002), assessment is part of the "authentic practice of a profession" (p. 196). Chamber and McNaught (2007) define "appropriate and authentic assessment" as one of the essential features of effective teaching. If not designed in accordance to the learning objectives of a course, program or discipline, the possible negative effects of assessment on student learning is also debated (Boud, 1990, p. 413). Evidently, all these studies meet on the common ground of a paradigm shift in higher education: a paradigm shift in which emphasis is put on 'student learning' as one of the main purposes of higher education and on the strategies needed to improve teaching in a way to enhance learning. Student learning is related to "promoting learning by motivating students, steering their approach to learning and giving the teacher useful information to inform changes in teaching strategies -assessment for and as learning" (Bloxham \& Boyd, 2007, p. 31). Accordingly, assessment approaches shift from "assessment of learning" that is summative in nature, to "assessment for learning" that depends on formative procedures (Black \& William, 1998; Stiggins, 2002; Broadfoot \& Black, 2004; Segers et al., 2009). Assessment for learning approach aims at the improvement of student learning through the education process by means of timely feedback that would inform the students about their progress in learning. In the view of Segers et al. (2009) along with fostering student learning, "assessment for learning" approach has positive effects on improving teaching practices by going beyond "pre-defined, norm-referenced standards" in teaching (p. 302). Different than summative assessment that is realized at the end of the education process, formative assessment is spread throughout this process (Popham 2008; Segers et al., 2009). Good teaching is redefined as activities that aim at achieving a "constructive alignment" between assessment, learning and instruction (Rust, 2002; Biggs, 2003). Within this framework, the student is expected to be an active participant of the learning process by taking more responsibilities for their learning. 
20-22 March, 2020

Berlin, Germany $10^{\text {th }}$ International Conference on Humanities, Psychology \& Social Sciences

Boud (1990) notes, in formative assessment, "students engage in the problems and discourse of a given area and are given encouragement, response and feedback on what they do, as appropriate, with a view to them becoming more effective in their learning" (p. 102). In the view of Knight and Yorke (2003), students are encouraged to take active part on learning through formative assessment since they are informed "about their performances, creating the conditions for loops of reflection and action that, in theory at least, spiral ever more widely outwards." In doing this, formative assessment contributes to self-development of students by helping them discover their personal skills and competencies and understand what stage they are in their own developmental process (Toohey 2002).

\section{Methodolody}

Qualitative research is deemed appropriate as a research methodology for the present inquiry on the challenges and opportunities in the assessment and evaluation processes in design education. Qualitative research is defined as a process of making sense of social life and human problems by inquiring with its own methods, which can be conducted through explaining the concepts, meanings and relationships based on observations, interviews and documents (Dey, 1993; Creswell, 1998; Merriam, 1998). The research process that is generally followed in qualitative research is from the part to the whole (inductive), as a pathway of the construction of knowledge. The role of the researcher is to discover, reveal and re-construct this information, which remains embedded in social reality, by analysing the data collected in the research process (Glaser \& Strauss, 1967). In the present study, it is aimed to examine the foundations of the problems experienced in the assessment and evaluation processes in design education, starting from the researcher's own experiences both as a design educator and as a design education researcher.

The data collection processes have been determined based on the observation that the above-mentioned problems resemble the challenges related to the assessment and evaluation processes in higher education as well as the problems that result in the characteristics of design education. Data collection process covers a systematic and extensive literature survey, and data analysis part is based on identifying the themes derived from literature survey. Literature review with a special focus on assessment in general and formative assessment in particular in higher education, and assessment and evaluation in design education was undertaken using five international online databases: (a) Academic Research Complete, (b) DOAJ: Directory of Open Access Journals, (c) ERIC (The Education Resource Information Center), (d) Art \& Architecture Source, and (e) JSTOR. The keywords of the literature search were selected as higher education, assessment, formative assessment, learning, feedback, design feedback/critique, and design education. The search covered empirical or theoretical articles from different emphases, time scales, and from different theoretical positions, written in English and published in academic peer-reviewed journals. By screening the article abstracts and full texts, studies that could potentially be related to current research have been identified, so the literature research has been refined. The refined literature survey was subjected to in-depth thematic analysis that is based on identifying the key themes covered within the literature related with the research questions. As a tool of "identifying, analysing and reporting patterns (themes) within data" (Braun \& Clarke, 2006, p. 79) and of 
20-22 March, 2020

Berlin, Germany

\section{$10^{\text {th }}$ International Conference on Humanities, Psychology \& Social Sciences}

"thematizing meanings" (Holloway \& Todres, 2003, p. 347), thematic analysis addressed, firstly, to the relationship between assessment and learning with reference to debates on 'assessment of learning' (summative approach) or 'assessment for learning' (formative approach). Under the general framework provided through this theme, the patterns grounded in the analysis are categorised as follows: (1) the role of ingrained conventions of assessment that informs tutors' teaching practices, (2) the role of language and one-to-one communication in design feedbacks, and (3) the difficulty of evaluating the subjective design process objectively.

\section{Results and Discussion}

\section{Ingrained conventions of assessment informing tutors'teaching practices}

Architecture and design education is based on ingrained traditions all over the world. Staring from the 'atelier' method of the Ecole des Beaux Arts School in the late 18th century, continuing with a shift towards modern design pedagogy in the mid-twentieth century, and progressing in the early twenty-first century toward a digital turn, the studio tradition in architecture and design education has not changed dramatically (Goldschmidt, 2002; Anthony 2012). For more than a century, there are many basic and common educational philosophies and pedagogical approaches that persist in the education of an architect and / or designer. While design education is based on such persistent traditions, it would be a misinterpretation to say that the evaluation methods that are effective in design education have changed a lot. On the contrary, the teaching and assessment practices in the field of design education continue to be affected to a large extent by a prevailing approach to design pedagogy (Moore, 2001; Scagnetti, 2017). It can also be said that the studio tutors' practice of giving feedback often carries the effects of their own learning experiences and the pedagogical models applied by own their tutors. As aforementioned, personal backgrounds and belief systems of the tutors, their conceptions of teaching and learning play part in their personal dispositions towards assessment (Knight \& Yorke, 2003). This is mostly the case for design studio tutors. The ways in which they approach to give design feedback and to facilitate design learning reflect the traces of the pedagogical methods that they used to experience, and adopted, from their professors. Schön (1985) is a pioneer in the field of design research who underlined the existence of a "repertoire" of ideas, design approaches, project examples or designer profiles drawn from their previous experiences, that a tutor uses while giving feedback to students in the design studio. The need for a systematic examination of the design studio tutors' critiquing habits and strategies in order to improve students' learning experiences in the design studio is a recent concern of academic studies in the field of design research (Oh et al., 2012).

The challenges in the teaching and assessment practices of the studio tutors can be recontextualized into the broader field of higher education literature. According to the conventional assumption, to be an expert in disciplinary field guarantees good teaching practice, and earning a $\mathrm{PhD}$ degree was enough for an academic to start teaching in a higher education institution without studying on higher education pedagogy or the learning styles of students. This view was challenged by Boyer (1990), who remarked that for an academician 
20-22 March, 2020

Berlin, Germany $10^{\text {th }}$ International Conference on Humanities, Psychology \& Social Sciences

to be an instructor in a higher education institution, he/she should not only be specialized in a disciplinary area, but also should be cultivated with the general knowledge and skills on the concepts of teaching, learning and assessment methods. However, Boyer (1990) criticizes, graduate programs are not training their students in such basic qualifications. Thus, graduates as novice academics start their teaching career without getting any pedagogical formation about how to teach and they face many difficulties in managing teaching. In the view of Evans (2013), "ensuring training opportunities for staff to enhance shared understanding of assessment requirements" is one of the key principles of effective feedback in higher education (p. 79). This problem is evident also in the field of design education. The tutors do not have pedagogical formations about 'how to teach design'; rather they often practice the pedagogical approaches and traditions they have experienced in their own education.

It is possible to associate the design studio tutor's lack of pedagogical formation and the dependence on their ingrained conventions of evaluation with the basic dilemmas of assessment in higher education. In the view of Boud (1990), these dilemmas result in several reasons: while academics "place a high value of critical analysis" on their teaching practices, they usually "uncritically accept" their assessment practices; what is more, the fact that there is a huge difference between the expectations from the students in real life situations and the expectations from them in academic settings are very different is complicating the understanding of the educational value of assessment (pp. 101-102). Boud (1990) goes on to explain the negative effects of these dilemmas on student learning by noting that for "meaningful learning" to occur, "students [should] engage with the subject matter for its own sake, not for that of an extrinsic demand" (p. 102). The overemphasis put on 'research' as opposed to 'teaching' in academic performance assessment of the faculty in higher education institutions (Boyer 1990) can also be mentioned when the instructors' attitudes toward assessment is under discussion. The mainstream higher education policies that promotes reward of research and scholarly publication rather than the achievements in teaching hardly support the reflective endeavours of instructors to inquire and improve teaching and assessment practices (Smith \& Lipnevich, 2009). However, undoubtedly, the assessment of the quality of learning can hardly be dissociated from the evaluation of the quality or excellence in teaching. Thus, the initiatives to promote assessment for learning should also address the issue of 'effective teaching' that facilitates learning, bringing forth a responsibility on the part of the instructor.

\section{The role of language and one-to-one communication in design feedbacks}

The one-to-one communication between the tutor and the students, upon which feedbacks dwell, may cause part of the problems experienced in assessment and evaluation practices in design education. Such communication affects the atmosphere of the studio that involves: the communication modalities facilitated by actors, the language constructed and re-constructed in feedbacks, the meaning-making through the use of langue and the way all these practices contribute to the development of professional identity of design students.

For Stiggins (2004), the "context" that determines the "classroom climate" is one of the characteristics of high quality formative assessment. The context is determined by whether there is a supportive education environment and students are encouraged to learn from their 
20-22 March, 2020

Berlin, Germany $10^{\text {th }}$ International Conference on Humanities, Psychology \& Social Sciences

mistakes. In a similar vein, Evans (2013) underlines the influence of the interactions and communication modalities between the teacher as the "giver" and the student as the "receiver" of feedback on the nature of "feedback landscape" in education settings (p. 107). In design education, the communication modalities that involve varied discursive and non-discursive practices employed by the tutor and the students influence the "climate" or the "landscape" shaping a design studio (Shreeve et al., 2010; Svensson \& Edstrom, 2011; Wong, 2011; Oh et. al., 2012; Hall, 2000, cited in Belluigi, 2016; Wong, 2011; Orr \& Bloxham, 2012). Speech or language, drawing, gestures and body language are among the communication modalities that are employed while giving and receiving feedbacks in the design critique sessions. Speech, as the primary tool of communication in design critiques, allows the tutor to explain the potentials/constraints of a project not by telling what is wrong/right, or what should be done, but rather by asking questions in order to encourage the student to think in alternative perspectives. For the student, speech serves for explaining the design process, how he/she responded to the design problem, what are the features considered while developing alternative solutions to it. The tutor also uses drawing or sketching that help to deliver their ideas about students' projects or the examples they want open to discussion (Anthony 1991; Ulusoy 1999; Oh et. al., 2012). Gestures and facial expressions of the tutor may also deliver implicit information to students about design feedbacks. What is more, the evaluation of design projects may also be informed by norms, values or accepted behaviours that are peculiar to design education. As underlined by Oh et al. (2013), a tutor may combine a multiplicity of communication modalities while giving feedback to student's projects (p. 311).

Goldschmidt (2002) explains that the feedback session based on one-to-one communication is expected to encourage students" "to learn how to design, and to enhance his or her understanding of designing," and during this process, students are "extremely sensitive to the nature of one-on-one sessions and respond to the instructor's 'style' of teaching, which varies greatly from one instructor to another" (p. 430). For Goldschmidt (2012), the fact that usually the tutor gives feedback to students leads to a vulnerability of the contribution of design evaluation to the personal growth of students (p. 431). In the view of Dannels et al. (2008), design feedback that occurs in critique sessions demonstrates "expected communication competencies in design studios, which involves interaction management, demonstration of design evolution, transparent advocacy of intentional explanation of visuals, and the staging of the performance" (p. 1.). The language is also an indicator of the pedagogical model that occurs in a design studio. When the feedback process is realized through the master-apprenticeship model, the tutor plays the role of a source of "expertise" or "authority", the students get "corrections" of their projects and they tend to adapt the discursive positions of their masters (Swann 2002; Belluigi 2016). On the other hand, the tutor acting as a "facilitator", not only create better communication channels with students, but also support the formation of an environment of "negotiation" (McDonnell, 2016; Belluigi, 2016) that would help students to develop their projects. Thus, feedback genres in relation to the language occurring in the design studio have an impact on student learning and the degree of their involvement into learning process. Depending on the type of language, design critique can be collaborative, consultative, interpretive, investigative, judgmental, directive, hierarchically driven, etc. (Dannels \& Martin, 2008, p. 151). In the view of Goldschmidt (2002), the good tutor or coach "appears to know how to engage the student in a 
20-22 March, 2020

Berlin, Germany $10^{\text {th }}$ International Conference on Humanities, Psychology \& Social Sciences

conversation" (p. 434). Design feedback should go beyond one-way communication from the tutor as expert to students as novice designers, and evolve into a two-way interaction in the design studio into which all actors participate (Goldschmidt, 2002; Wong, 2011). Assessment in design education also involves peer review/evaluation in which students are encouraged to express their ideas and criticism about their friends' projects in the studio environment (Gray, 2013).

Language occurring in design critiques/feedbacks also acts as a "meaning-making" tool facilitated both by the tutor and the students in the design studio (Straub, I996; Scagnetti, 2017). When language acts not only a "representational" but also a "constructive" role, evaluation of design projects becomes not only a means of measurement, but also a means of collaborative meaning-making process (Mitchell, 1998, p, 31). The collaborative meaningmaking through design critique derives from an "exchange" in which ideas are brought into being through talking and also continually are made and remade through the communication between actors (Mitchell, 1998, p. 31 and p. 34). In the view of Orr and Bloxham (2012), "the design making itself is non-verbal but the meaning-making that surrounds this design making resides in language" (p. 237). What is at issue is a "discoursal creation of the value of the student work" (Orr \& Bloxham, 2012, p. 246). Scagnetti (2017) notes that, when design feedback facilitates "interpretation", "exploration" and "comparison", instead of being "directive" and/or "judgmental", it encourages meaning making, and in this way facilitates student learning (p. 785). This communication is also based on discipline-specific concepts, and evolves into a language shared by all designers. In this way, communication through design feedback contributes to the formation of a learning community in the design studio and the tutors and students participate in this community as learners. The act of design and the evaluation of design support the development of dialogical interaction between tutor-student and student-student, which in turn paves the way for the development of students discursive positions and identities as designers. Oak (2000) explains: "through talking and hearing talk about their projects, the students learn what to expect of design and what is expected of them if they are to become professional designers" (p. 93). In other words, students learn how to think and act as a designer, to use a practice-oriented discourse, to criticize other students' projects by using this discourse, and to perceive themselves as members of a community of designers (Dannels \& Martin, 2008; Wong, 2011). Accordingly, the language and dialogue facilitated through design feedback becomes a tool for identity development, contributing to practical and disciplinary professionalization in design education (Oak, 2000).

\section{The difficulty of evaluating the subjective design process objectively}

When the role of language and one-to-one communication in design feedbacks is under debate, a remark should be made to the concern for objectivity in design assessment. The oneto-one relationship established between the tutor and students, on the one hand allows the tutor to explore the learning styles and orientations of their students, and on the other hand, it can also make it difficult to be neutral at a certain point of design assessment. Students expect the design feedbacks to be rational, unbiased and objective, presenting the negative and positive aspects of their projects with clear justifications explaining the reasons why. Accordingly, one of the challenges of design assessment results in the problematic 
20-22 March, 2020

Berlin, Germany $10^{\text {th }}$ International Conference on Humanities, Psychology \& Social Sciences

relationship between the subjectivity of the design process and the expected objectivity of the evaluation procedures. It is usually confusing whether the process, the product as the outcome of the process or the person as the designer is being evaluated (Ehmann, 2005; de la Harpe \& Peterson, 2008; de la Harpe et al., 2009).

The uncertainty stems from several reasons. First of all, design is based on a creative process and designing skill is also related to creative abilities of students, and this complicates defining the criteria upon which the assessment of the process and the product would be based (Orr, 2007; Ellmers et al., 2008; de la Harpe et al., 2009). While it becomes a challenge for the tutors to define assessment focus and criteria, for the students it is not easy to understand what the tutors evaluate or 'where the grades come from' (Smith, 2013, p. 208). The subjective perceptions and tendencies of students toward design learning and assessment may also vary. The discussion by Knight and Yorke (2003) on the role of students" "self-theories" on how they interpret the assessment task and criteria is highly relevant for design assessment (p. 41). Students with varying knowledge, skills and personal backgrounds, when entering into higher education institutes often encounter a teaching and learning paradigm that they are not familiar with. This paradigmatic shift challenges the way they conceive teaching, learning and assessment (Smith \& Lipnevich, 2009, p. 280). Students' perceptions of assessment have a great impact on their educational experiences (Smith, 2013) by influencing their behaviours in accordance with the assessments demands (Gibbs, 1999), and their conception of themselves as students (Crooks, 1998) and as prospective professionals (Brown, 1997). Smith (2013) notes: "If we do not better understand students' perceptions, we are at best letting an important tool go underused and, at worst, sabotaging learning" (p. 205).

A student-oriented approach to assessment, Smith (2013) argues, necessitates more focus on students' learning orientations in the assessment practices, which is possible by getting students more involved into assessment practices. What is underlined here is not an attempt to personalize the design evaluation by delivering judgemental comments about the "studenting" approach of the student, rather than the quality of the design work (Orr \& Bloxham, 2012, p. 244). Alternatively, emphasis is based on the attempts for "exploring method of learning and effectiveness for design knowledge building, helping students learn from others, expanding conceptions through dialogue" (de la Harpe \& Peterson, 2008, p. 4). Such attempts designate an approach to assessment that takes into account the students as "self-determining" individuals; the idea that "students should become autonomous learners who can take responsibility for their learning" (Boud, 1990, p. 104). In the view of Evans (2013), the involvement of students in assessment is possible via giving feedbacks about assessment in higher education by "clarifying the role of the student in the feedback process as an active participant and not as purely receiver of feedback and with sufficient knowledge to engage in feedback", and by "ensuring support is in place to help students develop self-assessment skills including training in peer feedback possibilities including peer support groups" (p. 79). Within this framework, students should be encouraged and given the opportunity "to be skilled assessors of their own learning, and that of their peers, and be able to use or participate in a range of assessment approaches suited to subject, context, and purpose" (Absolum et al., 2010, p. 104). For Boud (1990) too, "self-assessment" is an effective strategy that would encourage students to become familiar and develop criteria for assessment and to take 
20-22 March, 2020

Berlin, Germany $10^{\text {th }}$ International Conference on Humanities, Psychology \& Social Sciences

responsibilities of their own learning (p. 110). Self-assessment is practiced in design education mostly in the form of peer review (Gray, 2013; Oh et al., 2012). Peer review can be self-directed among students, or at the beginning, the tutor may play the role of an initiator or facilitator by encouraging students to participate to a group discussion by expressing their opinions. When students are asked by the tutor to explain their initial ideas, how they developed these ideas as they progressed in the design process, or the strategies and methodologies they used, it helps both the student to reflect on his/her own experiences, but also it helps other students to realize different directions that they did not consider yet. Peer review gives room for students' voice in the design critique (Gray, 2013). While giving feedback to each other's projects, on the one hand each student engages in shaping of their own positions as designers, on the other hand students learn from each other.

Another way to include the student in the design assessment processes is consider the student's in-studio performance as an integral part of design evaluation. This brings us back to the initial question of whether the process or the product is being evaluated. However, this question can be re-formulated as such: Is it possible to facilitate design assessment where the process and the product as the outcome of design process are handled together? This question is addressed in scholarly research that examines assessment strategies through which the traces of the process could be seen on the final product. Arguing that to separate process and product from each other is problematic by itself, Orr and Bloxham (2012) note; "[t]he student submission is a body of work that seamlessly encompasses the development and realization of a particular idea"; accordingly, the "perceptions of the product appear to be influenced by the judgements of the process" (p. 242).

In design education, the evaluation of the process actually involves the search for a "quality" that includes evaluating each student's own development process and the process of developing a designer (Orr \& Bloxham, 2012, pp. 247-48). The search for quality concerns the evaluation criteria. The transparency and objectivity of assessment criteria is essential for design assessment to facilitate effective teaching and learning in design education (Ellmers et al., 2008, p. 2). This is not limited to design education, but is a prerequisite for learningoriented assessment practices generally in higher education. Students expect assessment criteria to be clear and coherent for them in order to be able to understand their mistakes or deficiencies and to monitor the level of their progress in their own learning process. Along with transparency, the concepts of "fairness" (Segers et al., 2009), "validity" and "reliability" (Ramsden 2003; Ellmers et al., 2008, p. 2; Absolum et al., 2010, pp. 104-105), and "accuracy" and "relevance" (Smith \& Lipnevich, 2009, p. 282) are highlighted in studies that focus on the principles and strategies of good assessment. Students' concerns for grading are related with the expectations for unbiased judgement, accurate and equal evaluation of student abilities and performances, and appropriateness of the assessment to predetermined assessment demands and learning goals. For students, grade may have a dual meaning related either with the teachers as assessors or themselves/their work as what is being assessed. Boud (1990) argues that grading "acts as a kind of currency indicating what teachers value" (p. 103). A research by Smith (2013) revealed that students perceive grade "as a measure of performance on a given task or assignment" that reflects who they are now and who they are likely to be in the future, making a direct association between grades and their success or 
20-22 March, 2020

Berlin, Germany $10^{\text {th }}$ International Conference on Humanities, Psychology \& Social Sciences

failure (p. 216). Smith (2013) argues that the students think that grades sometimes do not reflect the quality of their work or how hard they studied; they even think the stylistic preferences and subjective evaluations of professors are given priority in grading design students works (p. 209). In the conditions that the assessment criteria are not clear or appropriate from students' perspective, Smith argues (2013) assessment may act as a "barrier" to student learning (p. 201).

\section{Conclusion}

This study aimed to examine the challenges and potentials of assessment and evaluation processes in design education within the broader framework of the relationship between teaching, learning and assessment in higher education. It focused on three essential problematic issues: (1) ingrained conventions of assessment informing tutors' teaching practices (2) the role of language and one-to-one communication in design feedbacks, and (3) the difficulty of evaluating the subjective design process objectively. The study mainly addressed these issues with reference to changing conceptions of assessment in higher education towards a more learning-oriented approach.

In the view of Boud and Falchikov (2006), for assessment procedures to be learningoriented, emphasis should be placed on how assessment can foster learning throughout life, beyond scheduled education programs or academic settings. This can be possible, for Boud and Falchikov (2006), when students' skills of learning how to learn are enhanced by the strategies of learning how to assess learning; to put it differently, when the role of students in higher education shift from "subjects of assessment" towards "active agents" of assessment processes (p. 402). Accordingly, teaching practices should be designed and implemented in ways to support the development of students as "assessors" themselves, which will pave the way for their active participation in the learning process. In this study it is revealed that formative assessment plays a critical role in this regard since it serves for this purpose; it helps overcoming learning difficulties and fosters behavioural change in students. The feedback processes specific to design education have a structure that allows students to gain skills to evaluate their own learning processes. Desk critique and especially peer critique methods have the potential for students to develop as active agents of assessment processes by removing the student from being a subject of assessment. But there are things to do in order to uncover this potential. As it is underscored in the present study, firstly, the clarity of the assessment criteria and their compatibility with the learning objectives of design education should be ensured. Strategies to reduce students' grade anxiety should be developed. More collaborative evaluation methods should be supported to balance the hierarchy between the evaluator and the one being evaluated in studio settings. By moving away from the masterapprentice model that has been influential throughout the twentieth century, studio environments in which tutor's pedagogic role is a "facilitator" or "reflective practitioner" should be created. One of the most effective methods in which this can be seen is the peer review method; in the studio environment, the tutor can play a role in facilitator to support peer review. 
20-22 March, 2020

Berlin, Germany

\section{$10^{\text {th }}$ International Conference on Humanities, Psychology \& Social Sciences}

In this study, results are reflective of the theoretical positions from a selected literature from the fields of higher education and design education. It is possible that results could suggest similarities with other disciplinary areas; however, they are not generalizable across contexts. In order to make any holistic interpretations about what good assessment is, the must be compared with the findings of further researches about the assessment practices in other education programs. Despite the limitations and cautions considering generalizability mentioned above, it is suggested that the findings have implications for improving assessment practices that would support student learning and the findings illustrate key features that constitute insights for additional research. The potential contribution of the paper might be seen mainly as offering a framework for further research on place of assessment in learning beyond design education in higher education settings.

\section{References}

[1] Absolum, M., Gray, J., Mutchmor, M., (2010). Clarity in the Classroom: Using Formative Assessment for Building Learning-Focused Relationships. Portage \& Main Press

[2] Aderonmu, P.A., Awoyera, P.O., Sholanke, A.B. \& Erebor, M.E. (2017). Professional methods of assessments in architectural design projects: A focus on the relevant parametric measures in selected Nigerian universities. Cogent Social Sciences. [Online]. 3. pp. 1-20. Available: https://doi.org/10.1080/23311886.2017.1328793.

[3] Anthony, K. H., (1991). Design Juries on Trial: The Renaissance of the Design Studio. New York: Van Nostrand Reinhold.

[4] Anthony, K. H. (2012). Studio culture and student life. In Ockman, J (Ed.), Architecture school: Three centuries of educating architects in North America (pp. 396-401). Association of Collegiate Schools of Architecture.

[5] Belluigi, D. Z. (2016). Construction of roles in studio teaching and learning. The International Journal of Art \& Design Education. [Online]. 35(1). pp. 21-35. Available: https://doi.org/10.1111/jade.12042

[6] Biggs, J., (2003). Teaching for Quality Learning at University. SRHE and the Open University Press.

[7] Black, P. and Wiliam, D. (1998). Assessment and classroom learning. Assessment in Education. [Online]. 5. 7-74. Available: https://doi.org/10.1080/0969595980050102

[8] Bloxham, S. and Boyd, P., (2007). Developing Effective Assessment in Higher Education: A Practical Guide. Berkshire, England: Open University Press.

[9] Blair, B. (2006), "At the end of a huge crit in the summer, it was "crap" - I'd worked really hard but all she said was "fine" and I was gutted." Art, Design \& Communication in Higher Education. [Online]. 5(2). pp. 83-95. Available:

https://doi.org/10.1386/adch.5.2.83_1 
20-22 March, 2020

Berlin, Germany $10^{\text {th }}$ International Conference on Humanities, Psychology \& Social Sciences

[10] Blythman M., Blair, B. and Orr, S., (2008). Critiquing the Crit: Student guide. Available: www.adm.heacademy.ac.uk/library/files/adm. . ./crit-student-guide.pdf.

[11] Boud, D. (1990). Assessment and the promotion of academic values. Studies in Higher Education. [Online]. 15(1). pp. 101-111. Available: https://doi.org/10.1080/03075079012331377621

[12] Boud, D. and Falchikov, N. (2006). Aligning assessment with long- term learning. Assessment \& Evaluation in Higher Education. [Online]. 31(4). pp. 399-413, Available: DOI: https://doi.org/10.1080/02602930600679050

[13] Boyer, E. L., (1990). Scholarship Reconsidered: Priorities of the Professoriate. Princeton, N.J: The Carnegie Foundation for the Advancement of Teaching.

[14] Braun, V. and Clarke, V. (2006). Using thematic analysis in psychology. Qualitative Research in Psychology. [Online]. 3. pp. 77-101. Available: https://doi.org/10.1191/1478088706qp063oa

[15] Broadfoot, P. and Black, P. (2004). Redefining assessment? The first ten years of assessment in education. Assessment in Education. [Online]. 11(1). pp. 7-27. Available: https://doi.org/10.1080/0969594042000208976

[16] Brown, N. L. (2003). How lecturers experience student-centred teaching. (Unpublished doctoral dissertation). University of Lancaster, Department of Educational Research, UK.

[17] Brown, G., (1997) Assessing Student Learning in Higher Education. London: Routledge.

[18] Chamber, D. and McMaught, C., (2007). Enhancing University Teaching. London and New York: Routledge.

[19] Creswell, J. W., (1998). Qualitative Inquiry and Research Design: Choosing among Five Traditions. Thousand Oaks, CA: Sage Publications.

[20] Cross, N. (2004). Expertise in design: An overview. Design Studies. [Online]. 25(5). pp. 427-441. Available: http://dx.doi.org/doi:10.1016/j.destud.2004.06.002

[21] Dannels, M. and Martin, K. N. (2008). Critiquing critiques: A genre analysis of feedback across novice to expert design studios. Journal of Business and Technical Communication. [Online]. 22(2). pp. 135-159. Available:

https://doi.org/10.1177/1050651907311923

[22] Dannels, D., Gaffney, A. H. and Martin, K. N. (2008). Beyond content, deeper than delivery: What critique feedback reveals about communication expectations in design dducation. International Journal for the Scholarship of Teaching and Learning. [Online]. 2(2). Available: https://doi.org/10.20429/ijsotl.2008.020212

[23] De La Harpe, B. and Peterson, F. (2008). A Model for Holistic Studio Assessment in the Creative Disciplines. ATN Assessment Conference 2008 Engaging students in assessment Conference Proceedings. Duff, A., Quinn, D., Green, M., Andre, K., Ferris, T. and Copeland, S. (Eds.). 20-21 November 2008, Adelaide, SA. 
20-22 March, 2020

Berlin, Germany $10^{\text {th }}$ International Conference on Humanities, Psychology \& Social Sciences

[24] De la Harpe, B., Peterson, J. F., Frankham, N., Zehner, R., Neale, D., Musgrave, E. and McDermott, R. (2009). Assessment focus in studio: What is most prominent in architecture, art and design? JADE. [Online]. 28(1). pp. 37-51. Available:

https://doi.org/10.1111/j.1476-8070.2009.01591.x

[25] Dey, I., (1993). Qualitative Data Analysis: A User-Friendly Guide for Social Scientists. London: Routledge Publications.

[26] Drew, L. and Shreeve, A. (2005). Assessment as Participation in Practice. 12th Improving Student Learning Through Assessment Symposium. Rust, C. (Ed). September 2004. London, Oxford: OCSLD, pp. 635-654.

[27] Ehmann, D. (2005) Using Assessment to Engage Graphic Design Students in Their Learning Experience. Paper presented at the 2005 Evaluations and Assessment Conference, 30 November -1 December, Sydney.

[28] El-Maaddawy, T. (2017) Innovative assessment paradigm to enhance student learning in engineering education. European Journal of Engineering Education. [Online]. 42(6), pp. 1439-1454. Available: https://doi.org/10.1080/03043797.2017.1304896

[29] Ellmers, G., Foley, M. and Bennett, S. (2008). Graphic design education: A revised assessment approach to encourage deep learning. Journal of University Teaching \& Learning Practice. [Online]. 5(1). pp 77-87. Available at: http://ro.uow.edu.au/jutlp/vol5/iss1/7

[30] Evans, C. (March 2013). Making sense of assessment feedback in higher education. Review of Educational Research. [Online]. 83(1), pp. 70-120. Available: https://doi.org/10.3102/0034654312474350

[31] Gibbs, G. (1999). Using assessment strategically to change the way students learn. In S. Brown \& A. Glasner (Eds.). Assessment Matters in Higher Education: Choosing and Using Diverse Approaches (pp. 41-53). Buckingham: SRHE and Open University Press.

[32] Glaser, B. G. and Strauss, A. L., (1967). The Discovery of Grounded Theory: Strategies for Qualitative Research. Chicago: Adline Publishing Company.

[33] Goldschmidt, G. (2002). 'One-on-One': A Pedagogic Base for Design Instruction in the Studio. Proceedings of "Common Ground", Design Research Society International Conference. Durling, D. and Shackleton, J. (Eds.). September 5-7, 2002, Brunel University, Stoke-on-Trent: Staffordshire University Press, pp. 430-437.

[34] Gray, C. M. (2013). Informal Peer Critique and the Negotiation of Habitus in a Design Studio. DRS // CUMULUS 2013 2nd International Conference for Design Education Researchers. Oslo, 14-17 May 2013, pp. 702-714.

[35] Hall, S. (2000). Who needs 'identity'? In P. du Gay, J. Evans, and P. Redman (Eds), Identity: A Reader (pp. 15-30). London: Sage.

[36] Holloway, I. and Todres, L. (2003). The status of method: flexibility, consistency and coherence. Qualitative Research. [Online] 3. pp. 345-357.Available: ttps://doi.org/10.1177/1468794103033004

[37] Knight, P. and Yorke, M., (2003). Assessment, Learning and Employability. Society for Research into Higher Education. 
20-22 March, 2020

Berlin, Germany $10^{\text {th }}$ International Conference on Humanities, Psychology \& Social Sciences

[38] McDonnell, J. (2016). Scaffolding practices: A study of design practitioner engagement in design education. Design Studies. [Online]. 45(Part A). pp. 9-29. Available: https://doi.org/10.1016/j.destud.2015.12.006

[39] Merriam, S. (1998). Qualitative Research and Case Study Applications in Education. San Francisco: Jossey-Bass.

[40] Mitchell, S. (1998). Making through talking. National Association for Fine Art Education. [Online]. 2(3). pp. 30-34. Available: https://doi.org/10.1177/1474022212467605

[41] Moore, K. D. (2001). The scientist, the social activist, the practitioner and the cleric: pedagogical exploration towards a pedagogy of practice. Journal of Architectural and Planning Research. 18(1). pp. 59-79.

[42] Oak, A. (2000). It's a nice idea, but it's not actually real: Assessing the objects and activities of design. International Journal of Art \& Design Education. [Online]. 19. pp. 8695. Available: https://doi.org/10.1111/1468-5949.00205

[43] Oh, Y., Ishizaki, S., Gross, M. D. \& Yi-Luen Do, E. (2013) A theoretical framework of design critiquing in architecture studios. Design Studies. [Online]. 34(3). pp. 302-325. Available: https://doi.org/10.1016/j.destud.2012.08.004

[44] Orr, S. (2007). Assessment moderation: Constructing the marks and constructing the students. Assessment and Evaluation in Higher Education. [Online]. 32(6). pp. 645-656. Available: https://doi.org/10.1080/02602930601117068

[45] Orr, S. and Bloxham, S. (2012). Making judgements about students making work: Lecturers' assessment practices in art and design. Arts and Humanities in Higher Education. [Online]. 12(2-3). pp. 234-253. Available: https://doi.org/10.1177/1474022212467605

[46] Popham, W. J., (2008). Transformative Assessment. Virginia, USA: Association for Supervision and Curriculum Development.

[47] Raison, G. and Pelliccione, L., (2006). Aligning Assessment Practices with Long Term Outcomes in Higher Education. Evaluation and Assessment Conference: Enhancing Student Learning.

[48] Ramsden, P., (2003). Learning to Teach in Higher Education, 2nd ed. London: Routledge Falmer.

[49] Rust, C. (2002). The impact of assessment on studio learning: how can the research literature practically help to inform the development of departmental assessment strategies and learner-centred assessment practices? Active Learning in Higher Education. [Online]. 3. pp. 145-157. Available: https://doi.org/10.1177/1469787402003002004

[50] Samuelowicz, K. \& Bain, J. (2001). Revisiting academics' beliefs about teaching and learning. Higher Education. [Online]. 41. pp 299 - 323. Available: https://doi.org/10.1023/A:1004130031247

[51] Scagnetti, G. (2017). A dialogical model for studio critiques in design education. The Design Journal. [Online]. 20(1). pp. 781-791. Available:

https://doi.org/10.1080/14606925.2017.1353024 
20-22 March, 2020

Berlin, Germany $10^{\text {th }}$ International Conference on Humanities, Psychology \& Social Sciences

[52] Schön, D., (1985). The Design Studio: An Exploration of its Traditions and Potential. London: Royal Institute of British Architects.

[53] Segers, M., Dochy, F., Gijbels, D. \& Struyven, K. (2009). Changing insights in the domain of assessment in higher education. Novel assessments and their pre-, post- and pure effects on student learning. In D. M. McInerney, G. T. L. Brown (Eds.). Student Perspectives on Assessment: What Students Can Tell Us About Assessment for Learning (pp. 297-319). Charlotte, New York: Information Age Publishing.

[54] Shreeve, A., Sims, E., and Trowler, P. (2010). 'A kind of exchange': learning from art and design teaching. Higher Education Research \& Development. [Online]. 29(2). pp. 125-138. Available: https://doi.org/10.1080/07294360903384269

[55] Smith, J. K. \& Lipnevich, A. A. (2009). Formative assessment in higher education: Frequency and consequence. In D. M. McInerney, G. T. L. Brown (Eds.). Student Perspectives on Assessment: What Students Can Tell Us About Assessment for Learning (pp. 279-296). Charlotte, New York: Information Age Publishing.

[56] Smith, K. M. (2013). Assessment as a barrier in developing design expertise: Interior design student perceptions on meanings and sources of grades. iJADE. [Online]. 32(2). pp. 203-213. Available: https://doi.org/10.1111/j.1476-8070.2013.01746.x

[57] Stiggins, R. J. (2002). "Assessment crisis: The absence of assessment for learning," Phi Delta Kappan, vol. 83, no. 10, pp. 758-765.

[58] Stiggins, R. J. (2004). "New assessment beliefs for a new school mission," Phi Delta Kappan, vol. 86, pp. 22-27.

[59] Straub, R. (1996). "Teacher response as conversation: More than casual talk, an exploration," Rhetoric Review, vol. 14, pp. 374-399.

[60] Svensson L and Edstrom A (2011) The function of art students' use of studio conversations in relation to their artwork. International Journal of Education and the Arts. [Online]. 12(5). pp. 1-29. Available: https://files.eric.ed.gov/fulltext/EJ937066.pdf

[61] Swann, C. (2002). Nellie is dead. Art Design and Communication in Higher Education. 1. pp. 50-53.

[62] Toohey, S. (2002). Assessment of students' personal development as part of preparation for professional work - is it desirable and is it feasible? Assessment \& Evaluation in Higher Education. [Online]. 27. pp. 529-538. Available:

https://doi.org/10.1080/0260293022000020291

[63] Ulusoy, Z. (1999). To design versus to understand design: the role of graphic representations and verbal expressions. Design Studies. [Online]. 20(2). pp. 123-130. Available: https://doi.org/10.1016/S0142-694X(98)00030-1

[64] Wenger, E., (2004). Communities of Practice: Learning, Meaning and Identity. Cambridge: Cambridge University Press.

[65] Wong, H. L. H. (2011). Critique: A communicative event in design education. Visible Language. [Online]. 45(3). pp. 221-247. Available:

https://www.tandfonline.com/doi/pdf/10.1080/14606925.2017.1353024 
20-22 March, 2020

Berlin, Germany $10^{\text {th }}$ International Conference on Humanities, Psychology \& Social Sciences 